DOI 10.31718/2077-1096.21.2.199

UDC 378.046-021.68:616.31:37.018.43:004-021.272

Maksymenko A.I.

\title{
DISTANCE LEARNING TECHNOLOGIES OF POSTGRADUATE DENTAL EDUCATION SYSTEM
}

Poltava State Medical University

The implementation of distance learning is carried out with the help of modern systems of distance education. They allow to teach and to assess the knowledge of interns and doctors quickly and easily, regardless of their location. The aim of the study. A comparative review of the most well-known distance learning platforms, wich are designed to organize the learning process and control learning with the help of Internet technology. System of distance education is a virtual classroom with the possibility to train interns and doctors from different regions of Ukraine at the same time. There are many educational platforms for distance learning nowadays, such as Moodle (Australia), iSpring Learn LMS (Russia), Collaborator (Ukraine), eTutorium LMS (Ukraine), Opigno (Belgium), Atutor (Canada). Moodle is a free platform that allows users to create individual courses. It supports more than 100 languages. iSpring Learn LMS is a simple and user-friendly system that is a paid alternative to Moodle. Collaborator is a platform that works effectively on all modern devices and browsers and is virtually independent of the software of the user's device. eTutorium LMS is a virtual distance learning system that allows to create an online course of any complexity quickly. Opigno is a modern free distance education system based on Drupal (a popular content management system). Atutor, like Moodle, is an open web-based e-learning system. Conclusion. Distance learning systems differ not only functionally, but also in the way they solve problems. The simplicity of use of the platform depends on the degree of its adaptation to the needs of the user and the ability to use all existing features and functions of the system.

Key words: distance learning platforms, education system, postgraduate education, doctor, intern, dentist.

The education system in universities has really changed in many countries around the world, including Ukraine, thanks to active implementation of modern technologies. Telecommunications, information and pedagogical technologies should be used as much as possible. The approach to the education system needs to be reviewed, because of the appearance of new pedagogical methods, new requirements for knowledge and the rapid development of information technology [1, 2, 6, 14, 21].

Distance education can be considered as an innovative form of learning nowadays. It allows student to acquire knowledge in the Internet under the supervision of a teacher.

The main feature of distance learning is the possibility of obtaining educational services by interns and doctors without visiting the higher educational establishment. The learning process, namely, studying of material, communication between the teacher and the student is carried out via the Internet and by sending the e-mail $[5,7,10]$.

An important aspect of distance learning is maintaining communication between participants of the learning process. Modern telecommunication technologies are used to ensure this task. If the method of synchronous distance learning is used, then the teacher and interns communicate online. If the asynchronous method of distance learning is used, then the communication is happening offline by sending tasks to e-mail $[3,4,8]$.

The employees of Peadiatric Dentistry Department (the Educational Institute of Postgraduate Education) PSMU use both abovementioned methods of distance learning in their work. It allows to achieve the most effective results.

The department uses the following forms of distance learning:

- video lectures, video conferences, different forums and discussion;

- chats-training sessions, involving the use of chat technologies. Such classes are conducted synchronously, namely, all participants are given temporary access to the chat;

- webinars. We mean distance learning, seminars, conferences, laboratory

work and other activities that are conducted using telecommunications and other Internet capabilities. Webinars differ from chat sessions by longer time of work (several days or weeks), as well as the use of an asynchronous method of communication [13].

The implementation of distance learning is carried out with the help of modern systems of distance education (SDE). They allow to teach and to assess the knowledge of interns and doctors quickly and easily, regardless of their location [11].

The aim of the study

A comparative review of the most well-known distance learning platforms, wich are designed to organize the learning process and control learning with the help of Internet technology.

SDE is a virtual classroom with the possibility to train interns and doctors from different regions of Ukraine at the same time. The variety of distance education systems is developing rapidly nowadays. More and more new distance learning platforms with various functionalities are appearing.

Possibilities the of distance education system:

1. To create a knowledge base. To save teaching materials, tutorials, videos, e-courses, tests and other educational content in one place. Students are able to go to the portal and study the necessary material at any convenient time.

Том 21, Випуск 2 (74) 
2. To control the quality of education. You can get detailed statistics in the SDE: what materials are studied by users, what score they get in solving test tasks, how much time they spent on training. You can monitor the level of studying and evaluate the success of doctors, who are studying at the department with the help of SDE.

There are many educational platforms for distance learning nowadays, such as Moodle (Australia), iSpring Learn LMS (Russia), Collaborator (Ukraine), eTutorium LMS (Ukraine), Opigno (Belgium), Atutor (Canada).

Moodle is a free platform that allows users to create individual courses. It supports more than 100 languages. The system offers tools for managing virtual classrooms, creating certificates and evaluating the success of educational programs using analytics [21].

The functionality and design of the platform can be completely customized. Ready plugins (modules) for testing, video courses and webinars, tracking statistics are in Moodle. For example, plugin The Webinar allows you to add webinars hosted using Adobe Connect. There are also forums and newsletters.

Moodle supports all modern formats (some of them are supported only through plug-ins). There is no built-in designer of educational content in Moodle. Developers recommend to use Courselab, Easygenera tor, iSpring Suite and QuizMaker to create tests and courses. Statistics and reports depend on the installed modules. You can customize the reporting system for any needs thanks to the large number of plugins in Moodle [22].

You can add users manually, import a file, invite them by e-mail or allow them to register themselves in Moodle.

The social network in Moodle allows teachers and students to send each other direct messages on the course forums. In addition, the system is supported on mobile devices, it supports other plugins (such as Microsoft Office), integration with OneNote and the ability to sell courses through PayPal [20].

iSpring Learn LMS is a simple and user-friendly system that is a paid alternative to Moodle. The platform does not require installation, it is ready to work immediately after registration, and technical support solves all tasks for updating, configuration and consults on work on the platform. The platform is entirely in Russian. You can download any number of courses, tests, books, text documents, videos in SDE [16].

The built-in platform for webinars allows to train interns and doctors from different cities of Ukraine at the same time. Recordings of webinars are saved, they can be watched at any time. The iSpring Suite is added to the SDE. It can help you to develop e-courses, tests, video lectures, interactive games quickly and without special skills in PowerPoint.

The teacher of the department has the opportunity to make a step-by-step curriculum for each cycle. For example, a two-week TI (thematic improvement) course in pediatric dentistry for doctors. The program can be divided into sections, each chapter should include theoretical materials and practical tasks: methodical materials, situational tasks, tests.

To control the level of knowledge, it is necessary to create an electronic test in iSpring Suite and to download it to the SDE. Doctors should solve it.

The system collects detailed statistics and helps the teacher keep track of who is actually learning and who is not. It is convenient to control the level of training in each unit and to evaluate the success of students with its help. There are 23 types of reports in it. SDE also automatically generates a summary table. Each user can see his position in the success rating and compare himself with others. The training course can be run from any device: laptop, tablet and phone. The educational material can be opened with the help of special mobile application even without an Internet connection [17, 19].

Collaborator is a platform that works effectively on all modern devices and browsers and is virtually independent of the software of the user's device. With Collaborator you can implement and automate the following functions:

- testing and evaluation (test tasks, situational tasks, surveys);

- individual and group training with the use of courses, training programs and individual tasks;

- creating your own courses with download formats (video, audio, PPTX, PDF, DOCX and many others);

- social function in real time (discussions, forums, comments, individual and group chat, feedback from the teacher, push-messages and emails);

- simplicity of use of webinars (automated compilation of knowledge base with delimitation of access rights if necessary);

- study and make reports on user activity with the support of infographics and the possibility of real-time updates $[9,18]$.

eTutorium LMS is a virtual distance learning system that allows to create an online course of any complexity quickly. It has a simple interface, includes a built-in webinar platform, course and test editor, dialog simulator. The platform is entirely in Russian.

You can start creating courses and registering students immediately after registering for eTutorium LMS. The functionality of this platform includes:

- course designer;

- sequence of courses and study materials;

- possibility to include trial modules;

- test designer with setting the question type;

- questionnaire to get feedback from users;

- tracking the progress of each participant, log actions watching webinars,

answers to questions and so on. ; 
- reports on the course, module, test;

- webinar platform with the layout of rooms.

The full functionality of eTutorium LMS is available for 14 days of the test period.

Opigno is a modern free distance education system based on Drupal (a popular content management system). It gives the opportunity to manage the educational programmes, track the progress of interns and doctors, using just one tool.

The program includes all the main components of the effective distance learning system. The Opigno system has the following features, namely, you can upload and manage educational material any which formats, including in video gallery, keep an eye on the success of interns, fill out the schedule of classes, to correspond to the forum.

Also Opigno offers users the online survey, the possibility of sending instant messages and chat, which gives the opportunity for rapid communication and effective collaboration between teacher and doctors [12, 15].

Atutor, like Moodle, is an open web-based elearning system. Its features include a built-in course editor, an adaptive interface and a creative community on Github, always ready to answer any question. ATutor is translated into 50 languages.

You can conduct courses and tests, collect statistics with the help of ATutor. The BigBlueButton module allows you to conduct webinars. There is support for forums and user activity tracking.

There is a built-in tests designer in ATutor. There are 8 types of questions: single choice, multiple choice, several answers, open answer, sorting, matching, matching in graphics, Likert scale [8].

You can add users manually, import a file, invite them by e-mail or allow them to register themselves in ATutor.

\section{Conclusion}

Distance learning systems differ not only functionally, but also in the way they solve problems. Therefore, there is no universal system in the SDE variety. Each service has specific aims. That is why any platform for distance learning has its advantages and disadvantages. The simplicity of use of the platform depends on the degree of its adaptation to the needs of the user and the ability to use all existing features and functions of the system.

\section{References}

1. Adamova I, Holovachuk T. Dystantsiine navchannia: suchasnyi pohliad na perevahy ta problemy [Distance learning: a modern look at the benefits and challenges]. Vytoky pedahohichnoi maisternosti. 2012;10:3-6. (Ukrainian).

2. Galii LV, Shulga LI, Ykushenko VA ta in. Vprovadzenny distanciinoi formi navchannia $v$ sistemu pisl'adiplimnoi osviti: problemni pitannia s'ogodennia [Introduction of distance learning in the system of postgraduate education: problematic issues of today]. Problemi bezperervnoi medichnoi osviti ta nauki. 2019;3(35):14-20. (Ukrainian).

3. Goncharova NG, Kirsanova OV, Svetlic kii AO. Realizacia modelei distanciinogo navchannia u vishih medichnih navchal'nich distanciinogo navchannia u vishih medichnih navchal nich zakladah [Implementation of distance learning models in higher farmacevticheskoi I medicinskoi nauki I praktiki. 2014;1(14):93-96. (Ukrainian).
Kaskova L, Kulay O, Artemiev A, Vashchenko I. Orhanizatsiya efektyvnoyi dystantsiynoyi dilovoyi narady [Organizing effective onlide business meeting]. APMM [internet]. 30Hrud2020 [cited 27Kvit2021];20(4):176-179. (Ukrainian).

5. Kitura O, Nevoit G, Nastroga T. Osoblyvosti dystantsiynoho navchannya likariv-interniv z fakhu «medytsyna nevidkladnykh staniv» [Peculiarities of distance training of intern doctors in the speciality "emergency medicine"]. APMM [internet]. 30Hrud2020 [cited 27Kvit2021];20(4):180-184. (Ukrainian).

6. Naumenko LYU, Leps'kyy VV, Borysova IS, Berezovs'kyy VM. Suchasni mozhlyvosti dystantsiynykh form na pislyadyplomnomu etapi osvity [Modern possibilities of distance forms at the etapi osvity [Modern possibilities of distance forms at the
postgraduate stage of education]. Visnyk problem biolohiyi i postgraduate stage of education]. Visnyk
medytsyny. 2017;2(136):225-228. (Ukrainian).

7. Platonova OM, Stoeva TV, Titkova OV. Dystantsiyne navchannya pry vykladanni pediatrychnykh dystsyplin: Vyklyky chasu [Distance learning in the teaching of pediatric disciplines: The challenges of time]. Medychna osvita. 2021;4:52-56. (Ukrainian).

8. Polyanskaya V, Zvyagolskaya I, Derevyanko T. Pedahohichnoorhanizatsiyni aspekty dystantsiynoho navchannya $v$ medytsyni [Pedagogical and organizational aspects of distance learning in medicine]. APMM [internet]. 21Ber2021 [cited 27Kvit2021];21(1):137-141. (Ukrainian).

9. Skrypnyk LM. Dystantsiyna medychna osvita: suchasni realiyi ta problem [Distance medical education: modern realities and
problems]. Arkhiv klinichnoyi medytsyny. 2012;2(18):116-118. problems].
(Ukrainian).

10. Stasyuk OA, Vyzhenko YEYE, Kuroyedova VD ta in. Vprovadzhennya elementiv dystantsiynoho navchannya $v$ pislyadyplomnu medychnu osvitu na kafedri pislyadyplomnoyi osvity likariv-ortodontiv [Implementation of elements of distance learning in postgraduate medical education at the Department of Postgraduate Education of Orthodontists]. Suchasna medychna Postgraduate Education of Orthodontists]. Suchasna medychna
osvita: metodolohiya, teoriya, praktyka [Modern medical education: methodology, theory, practice]: materialy Vseukr. navch.-nauk. konf. z mizhnar. uchastyu, m. Poltava, 19 bereznya 2020 r.; Poltava; 2020: 211-212. (Ukrainian).

11. Tomashevs'kyy VM, Novikov YUL, Kamins'ka PA. Ohlyad suchasnoho stanu system dystantsiynoho navchannya [Review of the current state of distance learning systems]. Naukovi pratsi:
naukovo-metodychnyy zhurnal. 2011; 148(160): 146-157. naukovo-me
(Ukrainian)

12. Filenko B, Roiko N, Starchenkol, ta in. Porivnyal'nyy analiz uspishnosti studentiv pid chas dystantsiynoho navchannya tradytsiynoyi formy osvity [Comparative analysis of students' academic performance in distance and in-class learning]. APMM. 2020;20(3):245-248. (Ukrainian)

13. Sheshukova OV, Polishchuk TV, Trufanova VP. Zastosuvannya elementiv dystantsiynoyi osvity $v$ pislyadyplomniy pidhotovtsi likariv-stomatolohiv [Application of elements of distance education in postgraduate training of dentists]. Realizatsiya Zakonu Ukrayiny "Pro vyshchu osvitu" u Vyshchiy medychniy ta farmatsevtychniy osviti Ukrayini [Implementation of the Law of Ukraine "On Higher Osviti Ukr in Higher Medical and Pharm of Ukraine "On Higher Education Ukraine]: Vseukrayins'ka navch.-nauk. konf. z mizhnar. Uchastyu, Ternopil', 21-22 trav. 2015 r.; Ternopil': TDMU; 2015: 493.
(Ukrainian).

14. Atreya A, Acharya J. Distant virtual medical education during COVID19: Half a loaf of bread. Clin Teach. 2020 Aug;17(4):418-419.

15. Bajpai $S$, Semwal M, Bajpai $R$, et al. Health Professions' Digital Education: Review of Learning Theories in Randomized Controlled Res. 2019 Mar 12;21(3):e12912.

16. Caton JB, Chung S, Adeniji N, et al. Student engagement in the online classroom: comparing preclinical medical student questionasking behaviors in a videoconference versus in-person learning environment. FASEB Bioadv. 2020 Dec 11;3(2):110-117.

17. George PP, Zhabenko O, Kyaw BM, et al. Online Digital Education for Postregistration Training of Medical Doctors: Systematic Review by the Digital Health Education Collaboration. J Med Internet Res. 2019 Feb 25;21(2):e13269.

18. Klibanov OM, Dolder C, Anderson K, et al. Impact of distance education via interactive videoconferencing on students' course performance and satisfaction. Adv Physiol Educ. 2018 Mar performance
$1 ; 42(1): 21-25$.

19. Kyaw BM, Posadzki P, Paddock S, et al. Effectiveness of Digital Education on Communication Skills Among Medical Students: Systematic Review and Meta-Analysis by the Digital Health Education Collaboration. J Med Internet Res. 2019 Aug 27;21(8):e12967.

20. Luo L, Cheng X, Wang S, et al. Blended learning with Moodle in medical statistics: an assessment of knowledge, attitudes and practices relating to e-learning. BMC Med Educ. 2017 Sep 19;17(1):170.

21. Memon AR, Rathore FA. Moodle and Online Learning in Pakistani Medical Universities: An opportunity worth exploring in higher Medical Universities: An opportunity worth exploring in higher
education and research. J Pak Med Assoc. 2018 Jul;68(7):1076-1078.

22. Servidio R, Cronin M. PerLE: An "Open Source", ELearning Moodle-Based, Platform. A Study of University Undergraduates' Acceptance. Behav Sci (Basel). 2018 Jul 16;8(7):63. 


\begin{abstract}
Реферат
ДИСТАНЦІЙНІ ТЕХНОЛОГІЇ В СИСТЕМІ ПІСЛЯДИПЛОМНОЇ ОСВІТИ ЛІКАРІВ-СТОМАТОЛОГІВ Максименко A.I.

Ключові слова: платформи дистанційного навчання, система освіти, післядипломна освіта, лікар, інтерн, стоматолог

Реалізація дистанційного навчання здійснюється за допомогою сучасних систем дистанційної освіти, які дозволяють швидко і зручно навчати і оцінювати знання лікарів-інтернів і лікарів-курсантів незалежно від місця їх знаходження. Мета роботи. Порівняльний огляд найбільш відомих платформ дистанційного навчання, призначених для організації навчального процесу та контролю за навчанням 3 використанням інтернет-технологій. Система дистанційної освіти - це віртуальний клас, де можна одночасно проводити навчання лікарів-інтернів та лікарів-курсантів з різних регіонів України. На сьогоднішній день існує безліч освітніх платформ для дистанційного навчання: Moodle (Австралія), iSpring Learn LMS (Росія), Collaborator (Україна), eTutorium LMS (Україна), Opigno (Бельгія), Atutor (Канада). Moodle - це безкоштовна платформа, яка дозволяє користувачам створювати індивідуальні курси, підтримує більше 100 мов світу. iSpring Learn LMS - це проста і зручна для користувача система, яка $€$ платною альтернативою Moodle. Collaborator - це платформа, яка ефективно працює на всіх сучасних пристроях і браузерах і практично не залежить від програмного забезпечення призначеного для користувача пристрою. eTutorium LMS - це віртуальна система дистанційного навчання, що дозволяє швидко створити онлайн-курс будь-якої складності. Opigno - це сучасна безкоштовна система дистанційної освіти, що заснована на Drupal (популярній системі управління контентом). Atutor, як і Moodle, це відкрита веб-система для електронного навчання. Висновок. Системи дистанційного навчання відрізняються не тільки функціоналом, але і тим, які проблеми вони можуть вирішити. Зручність використання платформи залежить від ступеня її адаптації до потреб користувача і вміння використовувати всі існуючі можливості і функції системи.
\end{abstract}

\title{
Рeфpepat
}

ДИСТАНЦИОННЫЕ ТЕХНОЛОГИИ В СИСТЕМЕ ПОСЛЕДИПЛОМНОГО ОБРАЗОВАНИЯ ВРАЧЕЙ-СТОМАТОЛОГОВ Максименко А.И.

Ключевые слова: платформы дистанционного обучения, система образования, последипломное образование, врач, интерн, стоматолог.

Реализация дистанционного обучения осуществляется с помощью современных систем дистанционного образования, которые позволяют быстро и удобно обучать и оценивать знания врачейинтернов и врачей-курсантов независимо от места их нахождения. Цель работы. Сравнительный обзор наиболее известных платформ дистанционного обучения, предназначенных для организации учебного процесса и контроля знаний с использованием интернет-технологий. Система дистанционного образования - это виртуальный класс, где можно одновременно проводить обучение врачейинтернов и врачей-курсантов из разных регионов Украины. На сегодняшний день существует множество образовательных платформ для дистанционного обучения: Moodle (Австралия), iSpring Learn LMS (Россия), Collaborator (Украина), eTutorium LMS (Украина), Opigno (Бельгия), Atutor (Канада). Moodle это бесплатная платформа, которая позволяет пользователям создавать индивидуальные курсы, поддерживает более 100 языков мира. iSpring Learn LMS - это простая и удобная для пользователя система, которая является платной альтернативой Moodle. Collaborator - это платформа, которая эффективно работает на всех современных устройствах и браузерах, практически не зависит от программного обеспечения пользовательского устройства. eTutorium LMS - это виртуальная система дистанционного обучения, позволяет быстро создать онлайн-курс любой сложности. Оріgno - это современная бесплатная система дистанционного образования, основанной на Drupal (популярной системе управления контентом). Atutor, как и Moodle - это открытая веб-система для электронного обучения. Вывод. Системы дистанционного обучения отличаются не только функционалом, но и тем, какие проблемы они могут решить. Удобство использования платформы зависит от степени ее адаптации к потребностям пользователя и умение использовать все существующие возможности и функции системы. 